\title{
CONFISCO E GESTÃO DO LUCRO INJUSTIFICADO POR CORRUPÇÃO PÚBLICA EM PORTUGAL
}

\author{
Fernando Torrão*
}

Resumo: Considerando as elevadas "cifras negras" normalmente atribuídas aos crimes de corrupção e, bem assim, as dificuldades de deteção do correspondente lucro ilícito, o presente artigo versa sobre alterações legislativas ocorridas em Portugal nos últimos anos, tendo como referência obrigações e recomendações internacionais.

Palavras-chave: Corrupção pública; sinalagma genético intencionado; crime organizado; deteção de lucro ilícito; confisco.

\section{CONFISCATION AND MANAGEMENT OF THE UNJUSTIFIED PROFIT BY PUBLIC CORRUPTION IN PORTUGAL}

Abstract: Considering the high "dark numbers" usually attributed to corruption crimes and the difficulties in detecting the corresponding illicit profits, this article deals with legislative changes in Portugal in

Recibido: noviembre 2017. Aceptado: julio 2018

* Professor de Direito Penal.

Faculdade de Direito Universidade Lusíada do Porto. Rua Dr. Lopo de Carvalho 4369-0006 Porto. Email: ftorrao@por.ulusiada.pt 
recent years, based on international obligations and recommendations. Keywords: Public corruption; intentional illicit act; organized crime; detection of illicit profits; confiscation.

\section{Introdução}

A corrupção é um flagelo internacional cujo combate, por diversas razões (carácter normalmente organizado em que se contextualiza; modelos encenados, por vezes sofisticados, da sua prática e de ocultação do lucro obtido; respetivas dificuldades de prova e de deteção do lucro ilícito; habitual dimensão internacional), se depara com múltiplos obstáculos. Diversos instrumentos jurídicos internacionais têm vindo a impor obrigações aos Estados nacionais com o objetivo de implementar e articular medidas aptas a superar as dificuldades.

Destacam-se, neste particular, a Convenção da Organização para a Cooperação e Desenvolvimento Económico (OCDE) contra a Corrupção de Agentes Públicos Estrangeiros nas Transações Comerciais Internacionais (1997), a Convenção relativa ao Combate Contra a Corrupção envolvendo funcionários da União Europeia ou de Estados-membros (1997), a Convenção Penal sobre a Corrupção do Conselho da Europa (1999) ou a Convenção contra a Corrupção das Nações Unidas (2003) e, no que especificamente se refere ao combate do lucro ilícito proveniente do crime organizado no contexto da União Europeia, entre outras, a Ação-Comum 98/699/JAI, as Decisões-Quadro 2001/500/JAI, 2003/577/JAI, 2005/212/JAI, 2006/783/JAI, 2007/845/JAI do Conselho da União Europeia ou a Diretiva 2014/42/EU do Parlamento Europeu e do Conselho.

As obrigações internacionais daqui decorrentes implicam o ajustamento da legislação penal nacional nesta matéria, sobretudo no plano da definição dos tipos legais de crime que abrangem o fenómeno da corrupção, no âmbito do regime das respetivas consequências jurídicas sancionatórias e na deteção, recuperação e gestão de lucro ilícito. Ressaltar os aspetos essenciais dessas alterações, em perspetiva crítica, constitui objeto 
deste trabalho que, considerando o nosso ethos cultural, social, político e jurídico, não pode deixar de acarretar um difícil e laborioso equilíbrio de concordância prática de princípios, valores e direitos com relevância constitucional.

\section{Corrupção pública}

Os tipos legais de crime de corrupção sufragados pelo Código Penal (CP) (artigos $372 .^{\circ}$ a $374 .^{\circ}$ ) enquadram-se no Capítulo IV ("Dos crimes cometidos no exercício de funções públicas"), do Título V ("Dos crimes contra o Estado") do Livro II (Parte Especial). O bem jurídico tutelado é a "autonomia funcional do Estado" que deve ser salvaguardada pela "integridade do exercício das funções públicas pelos seus funcionários" , isto é, pelo exercício dos poderes e funções de que o funcionário é titular de "modo leal e transparente (reto)".

Em causa está sempre o funcionário na aceção do artigo $386 .^{\circ}$ do $\mathrm{CP}$, o funcionário que detém "poderes (jurídicos) de representação do Estado, na sua veste de sujeito de direito público, rectius, enquanto "autoridade" $»^{2}$. Ao cometer crimes de corrupção previstos no $\mathrm{CP}$, abusando dos seus poderes públicos em benefício próprio ou de terceiro e, por isso, defraudando a auctoritas de que está investido, está o funcionário, naturalmente, a incorrer em crimes de corrupção pública.

Com o objetivo de combater a corrupção pública em contexto internacional e sabendo-se da tendência global da criminalidade organizada - em que normalmente se enquadra a corrupção -, o artigo $386 .^{\circ}$ do $\mathrm{CP}$ tem vindo a alargar o conceito de

1 AlBuQuerque, P.: Comentário do Código Penal à luz da Constituição da República e da Convenção Europeia do Direito do Homem, 3. ${ }^{a}$ ed., Lisboa, 2015, p. 1180.

2 CUNHA, D.: "Da corrupção (Do seu enquadramento jurídico no âmbito da tutela penal dos interesses do Estado. Erros legislativos e lacunas de punibilidade), em Manuel da Costa Andrade e outros, Direito Penal - Fundamentos Dogmáticos e Político-Criminais. Homenagem ao Prof. Peter Hünerfeld; Coimbra, 2013, p. 855. 
funcionário. As grandes referências de tal alargamento no plano dos instrumentos jurídicos internacionais são a já apontada Convenção contra a Corrupção das Nações Unidas de 2003 - que define "funcionário público", "funcionário público estrangeiro" e "funcionário público de organização internacional pública" - e as recomendações do relatório de 2010 do Grupo de Estados contra a Corrupção (GRECO).

Num primeiro momento e em traços gerais, as alterações à versão original do artigo $386 .^{\circ}$ do $\mathrm{CP}$, implementadas pela Lei n. ${ }^{\circ} 108 / 2001$, de 28 de novembro, detiveram-se, sobretudo, no alargamento do conceito de funcionário a magistrados, funcionários, agentes e equiparados da União Europeia e a magistrados, funcionários, agentes e equiparados de outros Estados-Membros da União. Já num segundo momento, a Lei n. ${ }^{\circ} 30 / 2015$, de 22 de abril, seguindo de perto as recomendações do aludido relatório do GRECO, configurou a versão atual do Código Penal, ampliando esse alargamento a magistrados, funcionários, agentes e equiparados de organizações de direito internacional público e a funcionários nacionais de outros Estados quando a infração seja cometida, total ou parcialmente, em território português ${ }^{3}$.

Mas não se esgota a corrupção pública na que se encontra prevista no Código Penal. Como bem salienta Damião da Cunha, o que se tutela neste diploma é o exercício de modo leal e transparente de apenas um feixe, um segmento de poderes públicos civis: os poderes administrativos e jurisdicionais ${ }^{4}$. O que significa que a corrupção pública prevista no Código Penal se limita às «denominadas funções "secundárias", ou seja,

3 Para uma análise crítica problemática sobre o atual artigo $386 .^{\circ}$ do CP (moldado pela Lei n. ${ }^{\circ}$ 30/2015), veja-se CUNHA, D.: “As alterações legislativas em matéria de corrupção (a Lei 30/2015, de 22 de abril, e suas consequências)". Julgar Online, 2016, pp. 4-30.

4 CUNHA, D.: "Da corrupção (Do seu enquadramento jurídico no âmbito da tutela penal dos interesses do Estado. Erros legislativos e lacunas de punibilidade), em Manuel da Costa Andrade e outros, Direito Penal - Fundamentos Dogmáticos e Político-Criminais. Homenagem ao Prof. Peter Hünerfeld; Coimbra, 2013, p. 856. 
aquelas que actuam em obediência às regras de legalidade (isto é, segundo os princípios de legalidade, objectividade ou imparcialidade) e que cumprem funções de "serviço público" »". Não se regulam as «denominadas funções "primárias" (das quais se destaca, naturalmente, a função legislativa), ou seja, aquelas que determinam a "legalidade" de outros órgãos (como é o caso dos administrativos ou jurisdicionais)»; nem a «denominada função política $[\ldots]$, aquela $[. .$.$] em que a decisão não está regulada pe-$ los critérios de legalidade, mas com base em outros critérios» ${ }^{6}$.

A corrupção pública ligada ao poderes legislativo, governativo, executivo e político ${ }^{7}$ encontra-se regulada em legislação especial, a Lei n. ${ }^{\circ}$ 34/87, de 16 de julho, para a qual remete, de resto, o n. ${ }^{\circ} 4$ do artigo $386 .^{\circ}$ do $\mathrm{CP}^{8}$.

5 CUNHA, D.: "Da corrupção (Do seu enquadramento jurídico no âmbito da tutela penal dos interesses do Estado. Erros legislativos e lacunas de punibilidade), em Manuel da Costa Andrade e outros, Direito Penal - Fundamentos Dogmáticos e Político-Criminais. Homenagem ao Prof. Peter Hünerfeld; Coimbra, 2013, p. 894-5.

6 CUNHA, D.: "Da corrupção (Do seu enquadramento jurídico no âmbito da tutela penal dos interesses do Estado. Erros legislativos e lacunas de punibilidade), em Manuel da Costa Andrade e outros, Direito Penal - Fundamentos Dogmáticos e Político-Criminais. Homenagem ao Prof. Peter Hünerfeld; Coimbra, 2013, p. 895.

7 Sublinha oportunamente Euclides Simões que a corrupção de "agentes públicos" traduz um «conceito em que, na aceção do artigo $2 .^{\circ}$ da Convenção de Mérida, se inscrevem também os titulares de cargos políticos» (SIMÕES, E.: "Contra a Corrupção (Propostas terapêuticas para uma endemia antiga. Julgar Online, 2014, p. 3).

8 Damião da Cunha fundamenta as razões pelas quais se não podem regular da mesma forma as funções primárias e secundárias do Estado e, portanto, a necessidade de haver legislação autónoma para a corrupção (e outros crimes) praticada por titulares de cargos políticos, criticando, porém - e com razão -, o facto de o regime jurídico aí estabelecido acabar por ser idêntico ao do Código Penal (veja-se CUNHA, D.: "Da corrupção (Do seu enquadramento jurídico no âmbito da tutela penal dos interesses do Estado. Erros legislativos e lacunas de punibilidade), em Manuel da Costa Andrade e outros, Direito Penal - Fundamentos Dogmáticos e Político-Criminais. Homenagem ao Prof. Peter Hünerfeld; Coimbra, 2013, pp. 895 ss). 
Também o funcionário militar se não inclui no conceito geral de funcionário do artigo $386 .^{\circ}$ do $\mathrm{CP}$, que apenas integra o funcionário civil, encontrando-se previsto no artigo $4 .^{\circ}$ do Código de Justiça Militar (CJM). Neste diploma incrimina-se a corrupção passiva e ativa de funcionários militares (artigos $36 .^{\circ} \mathrm{e}$ 37. ${ }^{\circ}$ do CJM).

Face ao exposto, interessa relevar que na corrupção pública em causa está o aproveitamento de poderes públicos para a prossecução de fins particulares. A corrupção pública poderá assim definir-se, em traços gerais, como o ato, do agente público (rectius, agente investido em funções públicas), de "comercializar" ("mercadejar") poderes públicos que detém, para benefício próprio (particular) ou de terceiro, traindo a confiança do Estado.

\section{A "cultura de corrupção" ou as principais críticas anteriores à Lei n. ${ }^{\circ}$ 32/2010, de 2 de setembro}

Tradicionalmente, em Portugal, grassa a ideia de que existem elevadas taxas de "cifras negras" quanto à prática de crimes de corrupção ${ }^{9}$. As razões que se imputam ao sistema de justiça começam na própria legislação, no modo como se constroem os tipos legais de crime ${ }^{10}$. Sabe-se que estes devem ser

9 Ideia que se funda, sobretudo, na circunstância de as estatísticas tenderem a revelar escassez de processos por corrupção no nosso país, mas diversos estudos atribuírem índices de corrupção elevados no contexto da União Europeia (neste sentido, veja-se, por exemplo, SANTOS, C.: “A corrupção [Da luta contra o crime na intersecção de alguns (distintos) entendimentos da doutrina, da jurisprudência e do legislador", em Manuel da Costa Andrade e outros, Liber Discipulorum para Jorge de Figueiredo Dias, Coimbra, 2003, p. 967).

10 Ainda que, nos crimes de corrupção, as dificuldades comecem, é consabido, nas próprias características normalmente envolventes deste género de criminalidade por motivo de estratégias utilizadas para camuflar as verdadeiras intenções das partes, que Luís Campos exemplifica: «prática em locais acessíveis apenas aos próprios interessados»; «interposição de uma ou mais pessoas que diluam a relação corruptor-corrompido»; «utilização de códigos verbais que despistarão qualquer suspeita, ou, se não o fizerem, sempre 
dogmaticamente rigorosos e, tal como prescreve o princípio da legalidade, deve o texto ser claro e simples, evitando-se, tanto quanto possível, conceitos indeterminados. Mas isto não é o bastante. Para a eficácia prática da lei penal, deve também o legislador ter em conta as regras de direito processual penal e toda a realidade envolvente. A lei deve considerar que a sua aplicação depende das regras do exercício da ação penal num processo formal. Deve, nesse sentido, ser clara e simples para poder ser aplicada de modo (tão) igual (quanto possível) pela Polícia, Ministério Público e Tribunais que atuam nos ritmos impostos pela lei adjetiva. Como devem também os elementos dos tipos legais de crime poder ser provados de forma credível no processo penal através de meios de prova lícitos, devendo, por isso, encontrarem-se os respetivos elementos subjetivos de tal forma vinculados a fatores objetivos que possam ser averiguados com facilidade e, por conseguinte, determinados de modo seguro ${ }^{11}$.

Face a tais exigências implicadas no princípio da legalidade penal, questionava Rodrigues de Almeida se efetivamente os tipos legais incriminadores de corrupção previstos no Código Penal português se encontravam construídos de modo a permitir enfrentar o fenómeno (da corrupção) com os contornos em que este se apresenta e se contextualiza nas sociedades ocidentais $^{12}$. Colocava o Autor (A.) em evidência a tese - não criminologicamente provada do ponto de vista científico, mas, ainda assim, em perspetiva pouco menos do que manifesta face à realidade atual - de a corrupção não se reduzir, bem ao contrário, em «ato pontual praticado apenas no exercício de funções

dificultarão a prova do seu verdadeiro significado» (CAMPOS, L.: “A corrupção e a sua dificuldade probatória - o crime de recebimento indevido de vantagem", $R M P$, ano 35 (2014), 137, p. 118).

11 Assim, com referência a Jescheck, ALMEIDA, C. R.: "Criminalidade organizada e corrupção", em Maria Fernanda Palma e outros, 2. ${ }^{\circ}$ Congresso de Investigação Criminal, Coimbra, 2010, p. 51.

12 ALMEIDA, C. R.: "Criminalidade organizada e corrupção", em Maria Fernanda Palma e outros, $2{ }^{\circ}$ Congresso de Investigação Criminal, Coimbra, 2010 , p. 50. 
administrativas e judiciárias por agentes de baixo escalão hierárquico» ${ }^{13}$.

Ora, antes das alterações implementadas pela Lei $\mathrm{n}^{\circ}$ $32 / 2010$, de 2 de setembro, a subsunção aos tipos legais dos crimes de "corrupção passiva (para ato ilícito e para ato lícito)" e "corrupção ativa" previstos no Código Penal (artigos $372 .^{\circ}$ a $374 .{ }^{\circ}$ ) exigia a conexão entre a solicitação ou aceitação de vantagem, ou sua promessa, pelo funcionário e o ato ou omissão funcional a praticar. Ainda que, desde a entrada em vigor da Lei n. ${ }^{\circ}$ 108/2001, de 28 de novembro, tivesse ficado esclarecida a desnecessidade de correspetividade entre as prestações de corrupto e corruptor (vantagem recebida e ato praticado) $)^{14}-\mathrm{e}$, portanto, do (que poderemos designar, tomando de empréstimo a linguagem jurídico-civil atinente à teoria geral do negócio jurídico, por) "sinalagma funcional" -, a verdade é que se mantinha a imposição de, pelo menos, um "sinalagma genético intencionado" para a consumação dos crimes (de corrupção), uma vez que se continuava a exigir (pelo menos) a solicitação ou (pelo mais) a aceitação, por parte do funcionário (para si ou para terceiro), de vantagem (patrimonial ou não patrimonial), ou a sua promessa, que tivesse em vista "um qualquer ato ou omissão"15 (contrário

13 ALMEIDA, C. R.: "Criminalidade organizada e corrupção", em Maria Fernanda Palma e outros, $2 .{ }^{\circ}$ Congresso de Investigação Criminal, Coimbra, 2010, p. 52.

14 Desnecessidade que, como refere Cláudia Santos, era já assim interpretada pela doutrina antes da entrada em vigor da Lei n. ${ }^{\circ} 108 / 2001$, de 28 de novembro, mas sem acolhimento, em geral, na jurisprudência (com análise pormenorizada a partir de estudos de caso, SANTOS, C.: "A corrupção [Da luta contra o crime na intersecção de alguns (distintos) entendimentos da doutrina, da jurisprudência e do legislador", em Manuel da Costa Andrade e outros, Liber Discipulorum para Jorge de Figueiredo Dias, Coimbra, 2003, p. $968 \mathrm{ss})$.

15 A consumação do crime de corrupção passiva implica, pelo menos, a solicitação, por parte do funcionário, de vantagem (patrimonial ou não patrimonial), para si ou para terceiro, que tenha em vista um qualquer ato ou omissão e, portanto, a necessidade da existência, ao menos, do "sinalagma genético intencionado", da disponibilidade para "vinculação" a "acordo ilí- 
aos deveres do cargo na corrupção para ato ilícito - artigo 372. ${ }^{\circ}$, n. ${ }^{\circ} 1$; não contrário aos deveres do cargo na corrupção para ato lícito - artigo $373 .{ }^{\circ},{ }^{\circ}{ }^{\circ} 1$ ). Estava implicada, na descrição típica, ao menos, a correspetividade entre vantagem atribuída ou prometida (corrupção ativa), solicitada ou aceite (corrupção passiva) e a intenção da prática de ato ou omissão, mesmo que tais prestações acabassem por se não realizar ${ }^{16}$.

cito"; mas prevê, também, o respetivo tipo legal, pelo mais (digamos assim), a própria aceitação (de proposta de outrem), por parte do funcionário, de vantagem (patrimonial ou não patrimonial), para si ou para terceiro, que tenha em vista um qualquer ato ou omissão, aludindo a descrição típica, neste caso, ao próprio "sinalagma genético", isto é, ao "acordo ilícito" (não meramente intencionado, mas realizado).

16 Ao referir-se à desnecessidade, «para a condenação penal», da «prova do denominado sinalagma entre a conduta do corrupto e a conduta do corruptor» (SANTOS, C.: "Notas breves sobre os crimes de corrupção de agentes públicos". Julgar, n. ${ }^{\circ} 11,2010$, p. 53), Cláudia Santos não desconstrói, em nossa perspetiva, a implicação de um sinalagma genético intencionado enquanto elemento constitutivo do tipo legal de corrupção passiva anterior à Lei n. ${ }^{\circ}$ 32/2010. Na verdade, o que defende a A., se bem entendemos, é que, no momento do acordo (ilícito intencionado) se não exige a "vinculação" a uma contrapartida exata à solicitação, aceitação de vantagem, ou respetiva promessa, pelo funcionário. Mas isso não apaga, quanto a nós, o essencial do sinalagma genético intencionado (o funcionário solicitar ou aceitar vir a praticar "um qualquer ato ou omissão [...]", por contrapartida à vantagem aceite, solicitada ou prometida). Existe, pelo menos, a disponibilidade para a "vinculação" a uma contrapartida, ainda que não especificada, não exata. Esta "vinculação" a uma contrapartida é, aliás, condição necessária à distinção entre corrupção própria e imprópria implicada nos anteriores artigos $372 .^{\circ}$ e $373 .^{\circ}$ (e nos atuais artigos $373 .^{\circ}$ e $374 .^{\circ}$ ) do CP. Sem a mencionada (disponibilidade para a) "vinculação", tal distinção não pode existir, uma vez que se torna impossível determinar se em vista se tem a prática de ato contrário, ou não, aos deveres de cargo. No exemplo dado por Cláudia Santos («se um autarca permite a um empresário a construção de um imóvel com volumetria superior à legalmente admitida e depois se torna proprietário desse prédio»), a conclusão de que não é necessária a prova de que cada um encarava o ato do outro como contrapartida exata do seu próprio ato é correta. Mas também será curial afirmar que tais factos (autarca permitir ao empresário a construção de imóvel com volumetria superior à legalmente admitida; autarca torna-se proprietário de um apartamento nesse prédio) permitem presumir, para além da dúvida razoável, o acordo ilícito intencionado (a que temos vindo a chamar sinalagma genético intencionado). E 
Na realidade, um tipo legal assim construído continuava a dirigir-se, sobretudo, à corrupção ocasional. Não tendia a abranger a corrupção sistémica, a que se vai tecendo ao longo do tempo, sem conexões ou sinalagmas (funcionais ou genéticos) definidos. Não criminalizava o que é verdadeiramente essencial: os comportamentos que vão urdindo a "cultura de corrupção"17.

Se, em exemplos simples, a $B$, funcionário público, após pedir a conta de um jantar em família em restaurante de luxo, lhe fosse comunicado pelo respetivo empregado que $X$ ("testa de ferro" de $A$, empresário, "contratado" por $Y$ por indicação de $A$ ), já a havia pago, ou o mesmo sucedesse a $C$, também funcionário, depois de solicitar a fatura para pagamento de estadia em hotel, não haveria, com esta matéria de facto provada, corrupção. Nem mesmo se $B$ ou $C$ aceitassem a vantagem patrimonial. Até porque nem se conseguiria, apenas com esta matéria de facto, enquadrar a situação em corrupção própria ou imprópria (e o enquadramento numa ou noutra era exigido para a prática de crime de corrupção), pois apenas existiria, naquele momento, o perigo de vir a condicionar decisões futuras do funcionário, não se sabendo, todavia, quais. E estes casos são paradigmáticos de situações em que se começa a tecer a criação de um "clima favorável" na Administração Pública. Se, mais tarde, a empresa de $A$ surgisse num determinado concurso público em cujo processo decisório $B$ ou $C$ detivessem poder, estes sentir-se-iam provavelmente condicionados na sua atuação por motivo do "clima favorável" enredado por $A$. Neste momento já se perceberia quais os atos a praticar, já se poderia, à partida, provar o acordo ilícito intencionado (e se a corrupção era própria ou imprópria), mas, entretanto, tornar-se-ia complicada a relação

este é elemento constitutivo dos tipos legais de corrupção (passiva e ativa). Só o anterior artigo $373 .^{\circ}$, n. $^{\circ} 2$ (a que nos referiremos na nota 18 ) e o atual artigo $372 .^{\circ}$ (recebimento indevido de vantagem), ambos do CP, prescindem verdadeiramente do sinalagma genético, do acordo ilícito, intencionado.

17 Basicamente assim: ALMEIDA, C. R.: "Criminalidade organizada e corrupção", em Maria Fernanda Palma e outros, $2{ }^{\circ}$ Congresso de Investigação Criminal, Coimbra, 2010, p. 53. 
entre os factos (pagamento de hotéis restaurantes, etc. e prática do ato do funcionário), porquanto se estabeleceriam, decerto, emaranhados de relações indiretas aptas a dificultar seriamente a prova das ligações entre $A$ e $B$ (e/ou $C$ ), por exemplo, e, por conseguinte, o acordo ilícito intencionado. E o favorecimento que daí pudesse advir neste ato decisório - e em outros que porventura se seguissem, envolvendo, acaso, outros representantes da empresa ou outros funcionários, gerando atos de mútuo beneficio - é paradigmático da tal "corrupção sistémica" que se foi urdindo, a "cultura de corrupção", da que efetivamente corrói a Administração Pública; da corrupção que urge combater e que, portanto, mais importa sancionar logo em momento inicial (nos casos exemplificados, uma vez provada, quanto ao lado ativo, a atribuição, ou promessa, de vantagem e, no lado passivo, implicando já dois crimes, a aceitação da mesma).

Bem se vê que tipos legais de crimes de corrupção que prescrevem, pelo menos na sua génese, a intenção de acordo entre corrupto e corruptor, a necessidade do mencionado sinalagma (genético) ${ }^{18}$ intencionado (ou acordo ilícito intencionado),

18 Tem razão Cláudia Santos ao afirmar que o teor do anterior (à entrada em vigor da Lei n. ${ }^{\circ} 32 / 2010$, de 2 de setembro) artigo $373 .^{\circ}$, n. $^{\circ} 2$ já sufragava a «corrupção sem demonstração do ato pretendido» (sem sinalagma genético intencionado) que incriminava condutas propensas à criação de um «clima de permeabilidade e de simpatia face a atos indeterminados, uma vez que a vantagem «não é compreensível no contexto das relações pessoais, mas apenas das relações funcionais» (SANTOS, C.: "Notas breves sobre os crimes de corrupção de agentes públicos". Julgar, n. ${ }^{\circ} 11,2010$, p. 54; e, mais desenvolvidamente no mesmo sentido, SANTOS, C.: "Os crimes de corrupção de funcionários e a Lei n. ${ }^{\circ} 32 / 2010$, de 2 de setembro", em Rui Carmo e Helena Leitão (coord.), As Alterações de 2010 ao Código Penal e ao Código de Processo Penal, Coimbra, 2011, pp. 14-20). Trata-se, sem dúvida, de um primeiro passo no sentido da criminalização dos "pagamentos para facilitação" e, portanto, no combate à "cultura de corrupção". Passo que se revelava tímido, porém, ao considerarem-se dois aspetos de decisivo relevo prático: primeiro - além da necessidade da prova da solicitação ou aceitação, pelo funcionário, de vantagem (patrimonial ou não patrimonial) indevida, era necessária também a prova de que essa vantagem proviesse de "pessoa que perante ele" [funcionário] tivesse tido, tivesse ou viesse a ter "qualquer pretensão dependente do exercício das suas funções públicas"; segundo (e 
se não adequam a um processo penal de estrutura acusatória, alicerçado no princípio in dubio pro reo, no qual se impõe que os factos incriminadores se provem para além de qualquer dúvida razoável. Não é, pois, de estranhar que muitos destes casos contextualizados em "cultura de corrupção" dificilmente pudessem ser objeto de prova segura e, por conseguinte, de condenação penal $^{19}$. E o problema não estava, obviamente, no processo penal de estrutura acusatória, baseado na presunção de inocência e no decorrente in dubio pro reo, instituído como princípio básico, porque elementar, das democracias liberais.

Para além das dificuldades suscitadas pela exigência de sinalagma (ainda que só intencionado) na incriminação da corrupção, outra dificuldade provinha da ampla distinção, quanto ao regime jurídico, entre a chamada corrupção própria (para ato ilícito) e a corrupção imprópria (para ato lícito): punível com moldura penal entre um a oito anos de pena de prisão, a primeira; punível com limite máximo até dois anos de pena de prisão, a segunda.

Impõe-se aqui considerar que, bem vistas as coisas, a correção e lealdade da Administração Pública e respetiva confiança dos cidadãos é abalada de modo idêntico, quer a promessa ou solicitação de vantagem tenham em vista um ato que se não enquadre no âmbito de competências do funcionário, quer perspetivem ato que se encontre já no âmbito da sua discricionariedade. Não será, pois, tão relevante aferir, como à primeira vista se poderia supor, se o ato praticado, ou a praticar, pelo funcionário ultrapassa os seus deveres de ofício ou, afinal, se contém no círculo das suas competências funcionais. Mais: é até na corrupção imprópria (a que visa ato compreendido na esfera

mais importante) - a moldura penal respetiva (contextualizada no âmbito da corrupção imprópria) cominava sanção pouco mais do que insignificante, tornando residual (até pelos riscos implicados na denúncia deste género de criminalidade) o contacto do crime com o sistema de justiça.

19 Assim ALMEIDA, C. R.: "Criminalidade organizada e corrupção", em Maria Fernanda Palma e outros, $2{ }^{\circ}$ Congresso de Investigação Criminal, Coimbra, 2010, p. 52. 
de competências do funcionário) que em maior grau se contribui para a "cultura de corrupção". A atribuição (ou sua promessa) de vantagem (patrimonial ou não patrimonial) para a comissão de ato legal é suscetível de criar hábitos de pagamento até para que o funcionário desempenhe, afinal, as suas funções, cumpra os seus deveres. Potencia que o funcionário coloque dificuldades ao mero cumprimento do dever, sugerindo, mais ou menos dissimuladamente, quiçá, que estas poderão ser superadas com a atribuição de uma vantagem. Tornando-se uso comum esta prática, corrompe-se o sistema. A corrupção passa a ser sistémica, cultural. O cidadão sente-se compelido a pagar para obter, afinal, prestações a que tem direito.

Esta tão ampla diferença de regime jurídico tinha, ainda, relevantes consequências no âmbito dos correspondentes prazos de prescrição do procedimento criminal. A corrupção própria prescrevia no prazo de dez anos (por aplicação do artigo $118 .^{\circ}$, n. ${ }^{\circ} 1$, b) do CP); a imprópria no prazo de cinco anos (artigo $\left.118 .^{\circ},{ }^{\circ}{ }^{\circ} 1, \mathrm{c}\right)$ do $\left.\mathrm{CP}\right)$.

As dificuldades de prova normalmente implicadas nos crimes de corrupção, o apertado prazo de prescrição do procedimento criminal e o reduzido limite máximo da moldura penal (que propiciava a aplicação de penas de substituição da pena de prisão como, v.g., a suspensão de execução da pena privativa de liberdade) levavam ao afastamento da corrupção imprópria dos tribunais.

Não se encontraria, pois - e não obstante as alterações de 2001 -, a legislação penal anterior a Lei n. ${ }^{\circ} 32 / 2010$, de 2 de setembro, particularmente vocacionada para contrariar a "cultura de corrupção".

\section{Alterações da Lei n. ${ }^{0} 32 / 2010$, de 2 de setembro}

\subsection{Recebimento indevido de vantagem}

Com as alterações da Lei n. ${ }^{\circ}$ 32/2010, de 2 de setembro, sufragou-se no Código Penal um novo tipo legal de crime, qual 
seja, o de "recebimento indevido de vantagem" (artigo 372. ${ }^{\circ}$ ). Ao criminalizar a solicitação ou aceitação, pelo funcionário (por si ou por interposta pessoa, com o seu consentimento ou ratificação), no exercício das suas funções ou por causa delas, de vantagem patrimonial ou não patrimonial indevida, este tipo de crime apresenta uma previsão legal ampla, conformando as orientações internacionais a que Portugal se encontra vinculado e sendo até mais ambicioso que outros ordenamentos da nossa família jurídica, tais como o alemão ou o suíço ${ }^{20}$. Na verdade, ao prescindir da exigência de um acordo para a prática de um qualquer ato ou omissão do funcionário, neste tipo legal prescinde-se não só do sinalagma funcional (como sucedia já, de resto, com o tipo legal de corrupção, passiva e ativa, anterior á Lei n. ${ }^{\circ}$ $32 / 2010$, de 2 de setembro), mas também do próprio sinalagma genético intencionado. $\mathrm{O}$ elemento subjetivo que subjaz ao sinalagma genético (acordo ilícito) intencionado, entre corrupto e corruptor, não se constitui como elemento constitutivo do tipo legal do crime "recebimento indevido de vantagem".

É verdade que, segundo as máximas de experiência comum, se poderá inferir que, dos comportamentos previstos na tipificação do "recebimento indevido de vantagem", exista(m) contrapartida(s) mais ou menos específica(s) da vantagem recebida, prometida ou solicitada. E, em última análise, é (ou são) essa(s) contrapartida(s) que se pretende(m) evitar com esta criminalização. Porém, em lugar de deixar tais inferências a cargo do julgador (que nem sempre serão seguras quando se exige o acordo ilícito intencionado, uma vez que se torna necessário inferir o género de atos específicos que constituem a contrapartida e, apesar de facilmente se deduzir que os haverá, difícil se torna especificá-los), o legislador assume o iminente perigo abstrato das contrapartidas. E, por consequência, o perigo (abstrato) de se tratar de comportamento atentatório da integridade e retidão

20 Quanto a este ponto, veja-se ALBUQUERQUE, P.: Comentário do Código Penal à luz da Constituição da República e da Convenção Europeia do Direito do Homem, 3. a ed., Lisboa, 2015, pp. 1178-1179. 
do exercício das funções públicas, da autonomia funcional do Estado. Ao ser dispensado o elemento subjetivo específico (que constitui o sinalagma genético, o acordo ilícito, intencionado), tradicionalmente ligado (como condição necessária) à criminalização da corrupção, é dado um passo no sentido da punição das constelações de casos em que o pagamento (ou sua promessa ou oferta) tenha em vista a criação do já mencionado "clima favorável na Administração Pública". O recebimento deve considerar-se indevido nas situações em que, desde logo, não seja devido nos termos da lei - e, portanto, não se justifique do ponto de vista funcional -, não se sustente na relação pessoal entre os intervenientes, nem se enquadre em comportamentos socialmente adequados, conformes aos usos e costumes. Não implica, como bem se compreende, a prova de um acordo ilícito intencionado ${ }^{21}$.

21 Não tem razão, em nossa perspetiva, Paulo de Sousa Mendes ao defender, inspirado na jurisprudência alemã do Bundesgerichtshof $(B G H)$, que o artigo 372. ${ }^{\circ}$ do CP implica "acordo ilícito intencionado" (MENDES, P. S.: "Os novos crimes de recebimento e de oferta indevida de vantagem", em Rui Carmo e Helena Leitão (coord.), As Alterações de 2010 ao Código Penal e ao Código de Processo Penal, Coimbra, 2011, pp. 39-41). É verdade que o tipo legal pretende evitar o oferecimento ou promessa de vantagem que tem em vista a «criação de uma boa-vontade relativamente a decisões futuras, a qual possa se ativada oportunamente» (MENDES, P. S.: "Os novos crimes de recebimento e de oferta indevida de vantagem", em Rui Carmo e Helena Leitão (coord.), As Alterações de 2010 ao Código Penal e ao Código de Processo Penal, Coimbra, 2011, p. 38). Mas isso não é mais do que oferecer ou prometer a vantagem motivada por razões funcionais (não pessoais), tornando-a socialmente inadequada (e, portanto, típica). Concorda-se, assim, que, para o enquadramento no tipo legal de crime - artigo $372 .^{\circ}, \mathrm{n} .{ }^{\circ} \mathrm{s} 1$ e 2 do $\mathrm{CP}$-, deve o julgador tomar em consideração, entre outras circunstâncias, «a relação do particular com o serviço, a posição do funcionário, o procedimento utilizado para concretizar a entrega da vantagem, a natureza, o valor e a frequência das vantagens» (MENDES, P. S.: "Os novos crimes de recebimento e de oferta indevida de vantagem", em Rui Carmo e Helena Leitão (coord.), As Alterações de 2010 ao Código Penal e ao Código de Processo Penal, Coimbra, 2011, p. 38-9). Só que tais considerações não implicam a prova da subjetividade de um acordo ilícito intencionado; apenas envolve a circunstância de a oferta (ou promessa) não ser devida nos termos da lei, não se enquadrando no âmbito normal das relações funcionais, nem 
Ao erigir-se em crime de perigo abstrato ${ }^{22}$ (de o funcionário vir a tomar certas decisões ou adotar comportamentos em contrapartida da vantagem, ou por esta condicionado), - que prescinde do elemento subjetivo específico, o tipo legal antecipa a tutela penal ao momento da solicitação ou aceitação da vantagem, superando dificuldades probatórias deste género de criminalidade. Como supera também diferenças de regime jurídico entre corrupção própria e corrupção imprópria, uma vez que o perigo abstrato de prática de ato em contrapartida, ou em situação de condicionamento, não distingue - nem podia distinguir, enquanto perigo abstrato - se este seria contrário, ou não, aos deveres do cargo. A mera solicitação ou aceitação do funcionário (por si ou por interposta pessoa, com o seu consentimento ou ratificação), no exercício das suas funções (ou por causa delas), de vantagem (patrimonial ou não patrimonial) indevida, é suficiente para a consumação do crime ${ }^{23}$.

se justificar do ponto de vista pessoal, não sendo, também por isto, socialmente adequada. E, não existindo o n. ${ }^{\circ} 3$ do artigo 372. ${ }^{\circ}$, esta exigência (de se tratar de comportamento socialmente inadequado) manter-se-ia, pelo que as críticas do A. a este preceito não procedem (MENDES, P. S.: "Os novos crimes de recebimento e de oferta indevida de vantagem", em Rui Carmo e Helena Leitão (coord.), As Alterações de 2010 ao Código Penal e ao Código de Processo Penal, Coimbra, 2011, p. 40.) Ou, então, a cláusula de inadequação social não se configura como pressuposto geral da tipicidade, por vezes sublinhada pelo legislador em alguns preceitos. Como não tem igualmente razão Luís Campos ao implicar a necessidade de negociação ilícita no halo conceitual do carácter indevido da vantagem (CAMPOS, L.: "A corrupção e a sua dificuldade probatória - o crime de recebimento indevido de vantagem", $R M P$, ano 35 (2014), 137, pp. $128 \mathrm{ss).}$

22 Também assim, entre outros, ALBUQUERQUE, P.: Comentário do Código Penal à luz da Constituição da República e da Convenção Europeia do Direito do Homem, 3. ${ }^{\text {a }}$ ed., Lisboa, 2015, p. 1180.

23 Consumação que opera, em nossa perspetiva, no exato momento em que tal solicitação ou aceitação é recebida pelo destinatário. Não será necessário que este efetivamente a conheça, mas que a receba (se, v.g., enviada por e-mail ou por fax basta que esta passe a constar do correio eletrónico do destinatário ou do seu aparelho de $f a x$, independentemente do momento em que este destinatário dela tome conhecimento), tratando-se, por isso, de crime de resultado (identicamente: CAMPOS, L.: "A corrupção e a sua dificuldade probatória - o crime de recebimento indevido de vantagem", $R M P$, ano 35 (2014), 137, 
Com as alterações implementadas pela Lei n. ${ }^{\circ} 41 / 2010^{24}$, de 3 de setembro, também na Lei relativa a crimes da responsabilidade de titulares de cargos políticos e de altos cargos públicos - Lei n. ${ }^{\circ}$ 34/87, de 16 de julho - se passou a incriminar, do mesmo modo, o "recebimento indevido de vantagem" (artigo 16. ${ }^{\circ}$ ).

Já o CJM não prevê similar tipo legal de crime.

Se o que se acaba de expor se reporta ao recebimento indevido de vantagem propriamente dito, isto é, aquele que implica como autor do crime o funcionário (artigo 372. $.^{\circ},{ }^{\circ}{ }^{\circ} 1$ do $\mathrm{CP}$ ) ou o titular de cargo político ou de alto cargo público (artigo $16^{\circ}$ da Lei . $^{\circ} 34 / 87$, de 16 de julho), antecipando a tutela penal da corrupção passiva (e sendo, por isso, crime específico), no essencial abrange também, mutatis mutandis, o preceituado no n. ${ }^{\circ}$ 2 do mesmo artigo $372 .^{\circ}$ do $\mathrm{CP}$ (e o n. ${ }^{\circ} 2$ do mesmo artigo $16 .^{\circ}$ da Lei n. ${ }^{\circ}$ 34/87) que antecipa a tutela penal (ao perigo abstrato) da corrupção ativa (este já crime comum), vale por dizer, ao (assim por vezes designado) pagamento indevido de vantagem.

\subsection{Corrupção passiva e ativa}

Implementado o novo tipo legal de crime ("recebimento indevido de vantagem") no artigo $372 .^{\circ}$ do CP através da Lei n. ${ }^{\circ}$

p. 123). Haverá, assim, tentativa se, por exemplo, a mensagem se extraviar. Este critério, que se vislumbra como o mais razoável nesta sede, até (mas não só) pela exatidão do momento em que ocorre - permitindo de modo rigoroso distinguir, por exemplo, a consumação da tentativa (veja-se infra, ponto 4.2) - baseia-se na regra geral da eficácia das declarações negociais adotado pelo direito civil, vale por dizer, no critério da teoria da receção, sufragado pelo artigo $224 .^{\circ}, \mathrm{n}^{\circ} 1$, primeira parte do Código Civil (sobre esta matéria, vejase, por exemplo, FERNANDES, L. C.: Teoria Geral do Direito Civil, II, 5. ed., Lisboa, 2010, p. 89 ss; VASCONCELOS, P. P.: Teoria Geral do Direito Civil, 8. ${ }^{\mathrm{a}}$ ed., Coimbra, 2015, pp. 455 ss).

24 Quanto às alterações implementadas pela Lei n. ${ }^{\circ}$ 41/2010, de 3 de setembro, com destaque para a extensão aos titulares de altos cargos públicos e para a equiparação às alterações ao Código Penal pela Lei n. ${ }^{\circ} 32 / 2010$, de 2 de setembro, veja-se SANTOS, C.: "Os crimes de corrupção de funcionários e a Lei n. ${ }^{\circ}$ 32/2010, de 2 de setembro", em Rui Carmo e Helena Leitão (coord.), As Alterações de 2010 ao Código Penal e ao Código de Processo Penal, Coimbra, 2011, pp. 25-27. 
32/2010, de 2 de setembro (e no artigo $16 .^{\circ}$ da Lei dos crimes da responsabilidade de titulares de cargos políticos e altos cargos públicos), pelas razões e com os objetivos enunciados, mantem-se o modelo clássico de incriminação da corrupção nos artigos $373 .^{\circ}$ e $374 .^{\circ}$ do mesmo diploma (e nos artigos $17 .^{\circ}$ e $18 .^{\circ}$ da mesma Lei n. ${ }^{\circ}$ 34/87), traduzido na "corrupção passiva" e na “corrupção ativa", respetivamente.

Sendo, também aqui, a "integridade no exercício das funções públicas" (no contexto da "autonomia funcional do Estado") o bem jurídico tutelado por tais incriminações, já os correspondentes tipos legais são entendidos como crimes de dano. Isto, porque se trata de incriminações baseadas em vantagem aceite ou solicitada por parte do funcionário para a prática de determinada ação ou omissão (ou seja: acordo ilícito intencionado, o tal sinalagma genético intencionado, em que o funcionário se dispõe a "vincular-se", ou aceita a "vinculação", à prática de ato ou omissão em troca de vantagem solicitada ou aceite), originando, assim, dano para o bem jurídico. A consumação do crime não implica a realização das correspetivas "prestações", isto é, a prática do ato ou a omissão por parte do funcionário e a atribuição da vantagem por parte do particular. Nem mesmo implica o acordo quanto à sua realização (apenas proposta do acordo). Não impõe "sinalagma funcional", nem "genético", configurando-se, nessa medida, em crime de mera atividade que se basta com o "sinalagma genético intencionado". Bem se compreendendo, não obstante, que o mero "acordo intencionado" é suficiente para causação de dano ao bem jurídico tutelado.

Pode dizer-se que o modelo proveniente Lei n. ${ }^{\circ}$ 32/2010, de 2 de setembro, se mantém, de resto, na linha do modelo anterior quanto aos elementos típicos de corrupção passiva e ativa. Persiste, com efeito, o pressuposto de um sinalagma genético intencionado (por parte do funcionário) na corrupção passiva e (por parte de outra pessoa) na corrupção ativa ${ }^{25}$.

25 Concorda-se com Cláudia Santos quando conclui que as alterações da Lei n. ${ }^{\circ} 32 / 2010$, de 2 de setembro não implicam, na corrupção própria, «qual- 
Importa, todavia, salientar qual o exato momento em que se dá a efetiva consumação dos crimes para que se possa distingui-la, com rigor, da forma tentada. Tanto mais quanto se, na corrupção passiva própria e imprópria a na ativa própria, a tentativa é punível nos termos gerais do artigo $23 .^{\circ}$, n. $^{\circ} 2$ do $\mathrm{CP}$ (por consignarem, estes tipos legais, pena máxima de prisão superior a três anos), também na corrupção ativa imprópria a tentativa é punível, desta feita (e por se tratar de pena máxima de prisão até três anos) por disposição especial do artigo $374 .^{\circ}$, n..$^{\circ} 3$, do mesmo CP.

Não constitui tentativa de corrupção ativa a mera oferta de vantagem ao funcionário que seja por este recebida e recusada ou que seja por este recebida, mas não compreendida, diferentemente do que é defendido por grande parte da doutrina e da jurisprudência ${ }^{26}$. Se é verdade que constitui elemento constitutivo do tipo legal a doação de vantagem ("quem por si, ou por interposta pessoa [...] der [...] vantagem) e que esta envolve um acordo (doação implica proposta e aceitação), também não é menos verdade que o tipo legal se basta, em alternativa, com a mera promessa de atribuir (ou de dar) essa mesma vantagem

quer modificação do regime jurídico» face ao anterior, «nem no que respeita aos seus elementos típicos, nem no que respeita à moldura penal prevista na norma base, que continua a ser a pena de prisão entre um e oito anos» e que na imprópria só se agrava a moldura penal (SANTOS, C.: "Os crimes de corrupção de funcionários e a Lei n. ${ }^{\circ} 32 / 2010$, de 2 de setembro", em Rui Carmo e Helena Leitão (coord.), As Alterações de 2010 ao Código Penal e ao Código de Processo Penal, Coimbra, 2011, p. 13); ainda que esta agravação não constitua fator despiciendo (cf., supra, nota 18).

26 Vejam-se as referências em ALBUQUERQUE, P.: Comentário do Código Penal à luz da Constituição da República e da Convenção Europeia do Direito do Homem, 3. a ed., Lisboa, 2015, pp. 1191-1192. Não é sustentável entender, desde logo, que a oferta recusada se queda pela tentativa atendendo ao elemento gramatical das normas de corrupção ativa e passiva cuja consumação opera claramente com a solicitação ou aceitação de vantagem ou com sua promessa. A questão está em determinar o momento exato da consumação que se afere pela eficácia destas declarações de vontade. Neste particular, já o vimos, deve prevalecer a teoria da receção (cf., supra, nota 23 ). 
e que, por isso, mesmo essa mera promessa é suficiente para a consumação do crime, independentemente de ser ou não recusada. A prática do crime de corrupção não implica necessariamente, como se vem referindo, o acordo ilícito ou o sinalagma genético. Implica, isso sim, o acordo ilícito (ou o sinalagma genético) meramente intencionado; que a promessa (na corrupção ativa) ou a solicitação (na corrupção passiva) se exteriorizem e sejam recebidas (já se referiu) pelo destinatário, desde que realizadas com a intenção (elemento subjetivo específico) de obter, em troca, a prática de um qualquer ato ou omissão. Assim, uma vez recebida pelo destinatário a promessa ou a solicitação de vantagem, encontra-se consumada a corrupção, independentemente da recusa (por parte dos destinatários) de tais propostas. Donde se reduzirá a tentativa (de corrupção) a constelações de casos em que exista mera exteriorização de tais declarações (promessa ou solicitação de vantagem, que, ao constituírem elementos do tipo legal, se traduzem em atos de execução), sem que estas sejam, por qualquer razão alheia à vontade do agente (v.g., extravio), recebidas pelos correspondentes destinatários.

Só assim, aliás, a punibilidade da tentativa de corrupção se assume como verdadeiramente útil, posto que a solicitação ou promessa recusadas implicam, como bem se compreende, o recebimento ou conhecimento de tais declarações pelo destinatário e, por isso, prefiguram, na legislação atual, crime de recebimento ou pagamento indevido de vantagem. Pelos crimes consumados do artigo $372 .^{\circ}$ (n..$^{\circ}$ s 1 e 2) do CP, tais solicitações ou promessas recusadas seriam puníveis (sem que fosse sequer necessário provar o elemento subjetivo específico). Queda-se, pois, a tentativa de corrupção (ou a tentativa de recebimento indevido de vantagem, caso se não prove o elemento subjetivo específico) pela solicitação (ou promessa) exteriorizada mas não recebida pelo destinatário ${ }^{27}$. E o legislador atribui forte relevo à tentativa neste género de crimes. No caso em que a moldura penal, em geral (artigo 23. ${ }^{\circ}$, n. $^{\circ}, 2$ do $\mathrm{CP}$ ), determinaria a não

27 Em conformidade com teoria da receção (nota 23 e nota anterior). 
punibilidade da tentativa - a corrupção ativa imprópria (punível com pena de prisão até três anos pelo artigo $374 .^{\circ}$, n. $^{\circ} 2$, também do CP) - o legislador, em especial (artigo $374 .^{\circ}$, n. $^{\circ} 3$, ainda do $\mathrm{CP}$ ), volta-se a insistir, impõe essa punibilidade (da tentativa) ${ }^{28}$.

\subsection{Corrupção própria e imprópria}

Referimos já que, em termos de gravidade de ilícito, não será particularmente relevante a diferença entre corrupção própria e corrupção imprópria, até porque esta última, em certa perspetiva, abrange situações concretas que acabam por se revelar mais vocacionadas para urdir as teias da "cultura de corrupção" ${ }^{29}$.

Será, assim, de aplaudir a atenuação da dissemelhança quantitativa das respetivas molduras penais operada pela Lei $n .{ }^{\circ}$ $32 / 2010$, de 2 de setembro, aproximando a gravidade sancionatória da corrupção imprópria à da própria. Terá constituído um passo no sentido da aproximação da corrupção imprópria ao sistema de justiça penal ${ }^{30}$.

\subsection{Prescrição dos crimes de corrupção e de recebi- mento indevido de vantagem}

Atentas as razões de política criminal de combate às cifras negras em matéria de corrupção, dado se tratar de um género de criminalidade que, à partida, não é propenso à imediata denúncia às autoridades, a Lei n. ${ }^{\circ} 32 / 2010$, de 2 de setembro, implementou profundas alterações ao artigo $118 .^{\circ}, \mathrm{n}^{\circ} 1$, a) do $\mathrm{CP}$, preceito que determina o prazo de quinze anos de prescrição do procedimento criminal. Se, anteriormente, este prazo se restringia a crimes puníveis com pena máxima de prisão superior

28 Tal previsão em especial torna-se desnecessária na corrupção ativa imprópria no quadro da Lei dos crimes de responsabilidade de titulares de cargos políticos, uma vez que, neste caso, a moldura penal é de pena de prisão até 5 anos (artigo $18 .^{\circ}$, n. $^{\circ} 2$ ).

29 Ut supra, ponto 3.

30 Aproximação também operada na Lei dos crimes de responsabilidade de titulares de cargos políticos (artigos $17 .^{\circ}$ e $18 .^{\circ}$ ). 
a dez anos, com as mencionadas alterações o preceito passou a incluir também, em regime especial, os crimes de corrupção e outros crimes de funcionário, compreendendo, ainda, os crimes de corrupção de titulares de cargos políticos (e, bem assim, de corrupção desportiva).

Trata-se de alteração controversa, uma vez que é suscetível de colocar em causa o princípio da proporcionalidade, um dos princípios básicos que alicerçam o nosso sistema jurídico-constitucional e o da generalidade das democracias liberais. Paulo Pinto de Albuquerque não hesita em considerar esta solução «constitucionalmente insustentável, por violação do princípio da proporcionalidade e concomitantemente do princípio da igualdade, em relação a alguns dos crimes mencionados» (nesta alínea a) do n. ${ }^{\circ} 1$ do artigo $118 .^{\circ}$ do $\mathrm{CP}$ ), nomeadamente no que se refere à «concussão, que é punível com pena até dois anos de prisão ou com pena de multa» ${ }^{31}$.

As alterações ao artigo $118 .^{\circ}$ do CP introduziram critérios (especiais) qualitativos face ao critério geral quantitativo que, em exclusividade, determinava (antes das alterações) os prazos de prescrição dos crimes. No que se refere aos crimes de corrupção pública (incluindo, naturalmente, a dos responsáveis de cargos políticos), justifica-se um regime especial, atentas as supramencionadas razões substantivas de política criminal. Sobretudo, no que se refere à corrupção em que o agente público é autor do crime - a passiva e o recebimento indevido de vantagem - e à corrupção própria quando o autor é qualquer cidadão - corrupção ativa própria -, uma vez que estes crimes, a operar o critério geral quantitativo, caberiam na alínea $b$ ) do n. ${ }^{\circ} 1$ do artigo $118 .^{\circ}$ do $\mathrm{CP}$, sendo o prazo de prescrição de dez anos. Já quanto à corrupção ativa imprópria e ao (designável) "pagamento indevido de vantagem" a questão é mais duvidosa, dado que se incluiriam estes crimes, em termos quantitativos, na

31 AlBuQuerque, P.: Comentário do Código Penal à luz da Constituição da República e da Convenção Europeia do Direito do Homem, 3. a ed., Lisboa, 2015, p. 478. 
alínea c) do mesmo . $^{\circ} 1$ do artigo $118 .^{\circ}$ do $\mathrm{CP}$ em que o prazo de prescrição ascende a cinco anos.

Se é verdade, todavia, no que se refere a estes crimes de corrupção - ativa e passiva, própria e imprópria, incluindo o recebimento (e pagamento) indevido de vantagem -, que, por um lado e por razões criminológicas e de política criminal, sempre se poderá argumentar a favor de prazos de prescrição idênticos para evitar assimetrias e descontinuidades (entre corrupção passiva e ativa, própria e imprópria e entre recebimento e pagamento indevido de vantagem) prejudiciais ao bom funcionamento do sistema de justiça, não deixará, por outro lado, de ter razão Paulo Pinto de Albuquerque quanto à inclusão de crimes como o de concussão (no artigo $118 .^{\circ}, \mathrm{n}^{\circ} 1, a$ ) do $\mathrm{CP}$ ).

\section{5. "Direito premial" na versão do "arrependido- colaborador"}

As características próprias dos crimes de corrupção, nomeadamente as inerentes dificuldades probatórias e a contextualização no âmbito da criminalidade organizada, levaram a que o legislador, desde a entrada em vigor da reforma ao Código Penal operada pelo Decreto-Lei n. ${ }^{\circ}$ 48/95, de 15 de março, concedesse espaço ao chamado "direito premial".

Se nas versões anteriores a 1995 apenas se consagrava a isenção de pena ao funcionário por arrependimento concretizado na mera restituição de valor recebido antes da prática do ato para o qual tinha sido aliciado e ao agente de corrupção ativa por aceitar o repúdio da promessa, a restituição do dinheiro ou outra vantagem patrimonial que havia feito ou dado ao funcionário, ou, então, no caso em que o cometimento do crime tivesse resultado de solicitação ou exigência do funcionário como condição para a prática de atos da respetiva competência, por participar o crime às autoridades ${ }^{32}$, a redação dada pelo Decreto-Lei n. $^{\circ}$

32 Regime que constava já na redação originária do Decreto-Lei n. ${ }^{\circ} 400 / 82$, de 23 de setembro (vejam-se os correspondentes artigos $420 .^{\circ}$, n. $^{\circ} 4$ e 423, n. $^{\circ} \mathrm{S}$ 3 e 4$)$. 
48/95, de 15 de março, sufragou a possibilidade de a pena poder ser especialmente atenuada, na corrupção passiva para ato ilícito, caso o agente (funcionário) auxiliasse concretamente na recolha de provas decisivas para a identificação ou a captura de outros responsáveis ${ }^{33}$. Surge aqui um verdadeiro regime de "direito premial" por colaboração com as autoridades na denúncia de crime de corrupção. A partir da entrada em vigor da Lei n. ${ }^{\circ}$ 108/2001, de 28 de novembro, a atenuação da pena por tal colaboração passou a ser obrigatória.

O direito premial é, já se sabe, um tema altamente controverso ${ }^{34}$ que suscita fortes críticas ${ }^{35}$, dúvidas, incertezas e que não encontra na estrutura processual penal portuguesa, tal como na da generalidade dos países da família jurídica romano-germânica, terreno favorável.

Não obstante, no âmbito da criminalidade organizada e no contexto dos chamados "megaprocessos" que esta é suscetível de propiciar, tivemos já ocasião de referi-lo, o direito premial e a figura do arrependido-colaborador assumem importância decisiva no âmbito da investigação e da produção de prova ${ }^{36}$.

Um dos principais problemas que ao sistema processual penal português (tal como, em geral, aos dos países da nossa família jurídica) se coloca na maioria dos crimes que admitem "colaboração premiada", prende-se com o facto de, à partida,

33 Regime plasmado no artigo $372 .^{\circ}$, n. $^{\circ} 4$.

34 Quanto às questões éticas implicadas na figura, no sentido da sua superação, veja-se LEITE, I.F.: ““'Arrependido”: a colaboração processual do co-arguido na investigação criminal", em Maria Fernanda Palma e outros, 2 . $^{\circ}$ Congresso de Investigação Criminal, Coimbra, 2010, pp. 381-383.

35 Veja-se, desde logo, SILVA, G. M.: "Bufos, infiltrados, provocadores e arrependidos: os princípios democráticos e da lealdade em processo penal". Direito e Justiça, Lisboa, ano VIII (1998), Tomo 2, Lisboa, pp. 27-34.

36 Veja-se TORRÃO, F.: "Princípio da oportunidade no quadro da criminalidade organizada e económico-financeira. Em especial a figura do "arrependido-colaborador"'., em Manuel Guedes Valente (coord.), IV Congresso de processo Penal - I Congresso Luso-Brasileiro de criminalidade económicofinanceira, Coimbra, 2016, pp. 163 ss. 
esta só poder começar a operar em sede de julgamento, uma vez que, pelos próprios princípios estruturantes do nosso processo penal - diferentemente do que se passa, é consabido, nos países de raiz cultural anglo-saxónica -, não pode operar no contexto de um espaço de oportunidade do Ministério Público (na investigação). Não é, por isso e em princípio, legítima, no nosso sistema processual, qualquer promessa de "prémio" ao arguido pelo Ministério Público em fase investigatória, porquanto se não encontra ao seu alcance o respetivo cumprimento. Caso o faça, para suscitar o arrependimento de um suspeito ou arguido e respetiva colaboração em matéria probatória, acabará por comprometer prova ao adotar meio enganoso na sua obtenção, gerando, nos termos do artigo $126 .^{\circ}$, n. $^{\circ}$, a) do Código de Processo Penal (CPP), nulidade insanável ${ }^{37}$. Veda-se, assim, a possibilidade de uma colaboração mais sustentada que acompanhasse o Ministério Público desde a fase de investigação, favorecendo uma recolha de provas mais vasta apta a consolidar as declarações do coarguido na fase de julgamento.

A estas dificuldades, acrescem as do valor probatório das declarações de coarguido. Como se sabe, em virtude do direito

37 Já assim por nós sublinhado (na esteira, v.g., de SILVA, G.M.: "Bufos, infiltrados, provocadores e arrependidos: os princípios democráticos e da lealdade em processo penal". Direito e Justiça, Lisboa, ano VIII (1998), Tomo 2, Lisboa, pp. 32 ss e LEITE, I.F.: ““'Arrependido”: a colaboração processual do co-arguido na investigação criminal", em Maria Fernanda Palma e outros, $2{ }^{\circ}{ }^{\circ}$ Congresso de Investigação Criminal, Coimbra, 2010, p. 394) em TORRÃO, F.: "Princípio da oportunidade no quadro da criminalidade organizada e económico-financeira. Em especial a figura do "arrependidocolaborador"'., em Manuel Guedes Valente (coord.), IV Congresso de processo Penal - I Congresso Luso-Brasileiro de criminalidade económicofinanceira, Coimbra, 2016. Caso se trate de processos em que os crimes nem sequer admitam a atenuação ou exclusão de pena por colaboração de arrependido, a prova obtida por promessa de vantagem a esse nível envolve ainda a proibição da alínea $e$ ) do n. ${ }^{\circ} 2$ do artigo $126 .^{\circ}$ do CPP ("promessa de vantagem legalmente inadmissível") com as mesmas consequências de nulidade insanável de prova (assim, BELEZA, T.: ““Tão amigos que nós erámos": o valor probatório do depoimento do co-arguido no processo penal português". RMP 19, n. $\left.^{\circ} 74,1998, \mathrm{p} .45\right)$. 
ao silêncio de que é titular, o (co)arguido não presta juramento e, portanto, a mentira por ele proferida não implica crime de falsas declarações (salvo no que respeita à sua identidade, nos termos do artigo $359 .^{\circ}$, n. $^{\circ} 2$ do $\mathrm{CP}$ ). Este enquadramento retira credibilidade ao depoimento e, sobretudo por isso, não vale este como prova testemunhal (artigo 133. ${ }^{\circ}, \mathrm{n}^{\circ} 1, a$ ) do $\mathrm{CPP}$ ), não devendo, por si, constituir fundamento bastante para condenação alheia. Apesar de o coarguido só estar impedido de hétero-incriminar no caso de exercer o direito ao silêncio para se não autoincriminar (conforme se retira do artigo $345 .^{\circ}$, n. $^{\circ} 4$ do CPP) e de o valor probatório do seu depoimento estar no domínio da livre apreciação da prova, entendem, e bem, jurisprudência ${ }^{38}$ e doutrina nacionais $^{39}$, que deve a condenação baseada nas suas declarações ser corroborada com outras provas ${ }^{40}$. O que se torna mais difícil de alcançar quando o (co)arguido apenas enceta a colaboração na recolha de outras provas na própria fase de julgamento.

No que se refere aos crimes de corrupção - e diferentemente do que se passa, v.g., nos crimes de branqueamento de capitais e terrorismo em que a atenuação da pena se apresenta como facultativa -, o legislador, já através da redação dada pela

38 Por exemplo: Acórdão do Supremo Tribunal Justiça (STJ) de 12-03-2008, relatado por Santos Cabral (disponível na internet em http://www.pgdlisboa. pt) e Acórdão do Tribunal da Relação de Guimarães de 09-02-2009 relatado por Estelita Mendonça (disponível na internet em http://www.dgsi.pt).

39 Já assim, entre outros, BELEZA, T.: ““Tão amigos que nós erámos”: o valor probatório do depoimento do co-arguido no processo penal português". $R M P, 19$, n. $^{\circ} 74,1998$, pp. 50 ss; SEIÇA, M.: O conhecimento probatório do co-arguido, Coimbra, 1999, p. 160; SANTIAGO R., "Reflexões sobre as declarações do arguido como meio de prova no Código de Processo Penal de 1987”. RPCC, 4, n. ${ }^{\circ}$ 1, 1994, p. 62; LEITE, I.F.: “““Arrependido”: a colaboração processual do co-arguido na investigação criminal", em Maria Fernanda Palma e outros, $2 .{ }^{\circ}$ Congresso de Investigação Criminal, Coimbra, 2010, p. 406.

40 Tópico também por nós já sublinhado em TORRÃO, F.: "Princípio da oportunidade no quadro da criminalidade organizada e económico-financeira. Em especial a figura do "arrependido-colaborador"”., em Manuel Guedes Valente (coord.), IV Congresso de processo Penal - I Congresso Luso-Brasileiro de criminalidade económico-financeira, Coimbra, 2016, p. 167. 
Lei n. ${ }^{\circ}$ 108/2001, de 28 de novembro, ao artigo $374 .^{\circ}-\mathrm{B}$, n. ${ }^{\circ} 2$, a) do $\mathrm{CP}$, impôs carácter obrigatório à atenuação especial da pena por auxílio concreto na obtenção ou produção de provas decisivas para a identificação ou captura de outros responsáveis. O que permite ao Ministério Público e ao juiz de instrução criminal, logo nas fases investigatórias, aludir à possibilidade de "prémio" em caso de "colaboração premiada". Se a colaboração ocorrer, encontra-se o Tribunal de Julgamento vinculado à atenuação especial da pena, favorecendo-se, assim, a consolidação de outras provas para além das declarações do coarguido.

Seja como for, o processo penal português não apresenta um estatuto definido e cabalmente regulamentado do "arrependido-colaborador". A figura apenas se vislumbra em algumas normas esparsas de direito substantivo, como, por exemplo, as dos artigos $374 .^{\circ}, \mathrm{n}^{\circ} 2$, a) e $368-\mathrm{A}, \mathrm{n}^{\circ} 9$ do $\mathrm{CP}$ ou as dos artigos $2 .^{\circ}$, n. $^{\circ} 5,3 .^{\circ}$, n. ${ }^{\circ} 2,4 .^{\circ},{ }^{\circ}{ }^{\circ} 6$ e $5 .^{\circ},{ }^{\circ} .^{\circ} 2$ da Lei n. $.^{\circ} 52 / 2003$, de 22 de agosto, relativas a crimes tendencialmente praticados em contexto organizado, como a corrupção, o branqueamento de capitais (e seus crimes precedentes) e terrorismo. Geram-se, inevitavelmente, assimetrias e descontinuidades entre os respetivos regimes jurídicos. No que se refere aos crimes de corrupção, o carácter obrigatório do "prémio" não deixa de promover um arrependido colaborador, que não apenas (mero) delator.

\section{Confisco ampliado}

A corrupção é um dos crimes característicos da criminalidade organizada e, por isso, integra o elenco dos chamados "crimes do catálogo" previsto na Lei n. ${ }^{0} 5 / 2002$, de 11 de janeiro (artigo $\left.1 .^{\circ}\right)$, respeitante às "medidas de combate à criminalidade organizada". Assim já originariamente, incluindo-se, agora, na respetiva versão atualizada (a oitava), operada pela Lei n. ${ }^{\circ}$ 30/2017, de 30 de maio, o crime de "recebimento indevido de vantagem" (artigo $1 .^{\circ}$, n. $\left.^{\circ} 1, e\right)$ ), acrescentado aos crimes de "corrupção ativa e passiva" e acompanhando as alterações ao Código Penal da Lei n. ${ }^{\circ} 32 / 2010$, de 2 de setembro, dissipando 
dúvidas (que houvesse) acerca de saber se o recebimento indevido de vantagem seria parte integrante dos crimes de corrupção.

Considerando - conforme consta na Decisão-Quadro 2005/212/JAI do Conselho da União Europeia, de 12 de fevereiro, relativa à perda de produtos, instrumentos e bens relacionados com o crime - que a «principal motivação da criminalidade organizada além-fronteiras é o lucro» ${ }^{41}$, determina o artigo $3 .^{\circ}$, n. $\left.{ }^{\circ} 2, c\right)$ do mesmo diploma que cada «Estado-Membro tomará as medidas necessárias para permitir a perda» (rectius, confisco), pelo menos, quando «for determinado que o valor dos bens do condenado é desproporcionado em relação aos seus rendimentos legítimos da pessoa condenada e um tribunal nacional estiver plenamente persuadido de que os bens em questão foram obtidos a partir de atividade criminosa da pessoa condenada $\rangle^{42}$. Trata-se de medidas que visam, sobretudo - tal como já na clássica perda de vantagens do crime -, finalidades de prevenção geral positiva que, nos crimes económicos (e não só), aptos a gerar lucro, se centra, em grande parte, na conformação das expectativas comunitárias de que "o crime não compensa".

Na sequência de um quadro jurídico - inspirado nos princípios da Convenção de 1990 do Conselho da Europa relativa ao branqueamento, deteção, apreensão e perda de produtos do crime - implementado na União Europeia desde a Ação-Comum 98/699/JAI, de 3 de dezembro, e da Decisão-Quadro 2001/500/ JAI do Conselho da União Europeia, de 26 de junho ${ }^{43}$, a ordem jurídica portuguesa, tal como sucedeu em outras ordens jurídi-

41 Cf. Consideração (1) da Decisão-Quadro 2005/212/JAI, de 12 de fevereiro, em Jornal Oficial da União Europeia, L 68/49, de 15.3.2005.

42 Jornal Oficial da União Europeia, L 68/51, de 15.3.2005.

43 Na Consideração (6) da Decisão-Quadro 2001/500/JAI, a propósito do combate ao branqueamento de capitais, sublinhava-se que este crime se encontrava no "cerne da criminalidade organizada», definindo-se que, para a respetiva erradicação, estava o Conselho Europeu decidido a garantir que fossem tomadas «medidas concretas para detetar, congelar, apreender e perder os produtos do crime» (Jornal Oficial das Comunidades Europeias, L $182 / 1$, de 5.7.2001). 
cas europeias - v.g., a inglesa e o Drug Trafficking Act de 1994, bem como o Proceeds of Crime Act de 2002 ou a espanhola e, desde logo, o Acuerdo Plenario de la Sala de lo Penal, do Tribunal Supremo de 5.10.1998, quanto a vantagens provenientes de tráfico de estupefacientes e branqueamento, e, bem assim, a Ley Orgánica 5/2002 para lucros obtidos por atividades criminosas cometidas em contexto de organizações criminosas ou terroristas $^{44}$-, havia já criado um regime de perda (confisco) mais ampliado do que o estabelecido na Decisão-Quadro. Através da mencionada Lei n. ${ }^{\circ}$ 5/2002, de 11 de janeiro, implementou um incidente processual, enxertado no processo penal (artigos $7 .^{\circ}$ a $\left.12 .^{\circ}-\mathrm{A}\right)$, que permite aplicar a figura do confisco do lucro injustificado ao arguido condenado por crime(s) do catálogo (no qual se incluía, como se referiu, a "corrupção ativa e passiva" e, agora, o "recebimento indevido de vantagem").

Este incidente processual atribui poderes ao Ministério Público, logo na acusação - e após apurar, em investigação paralela ao Inquérito, incongruência entre real património e rendimentos justificados (lícitos) -, para liquidar montante que deve ser declarado a favor do Estado. Tais poderes, previstos no artigo $8 .^{\circ}$, n. $^{\circ} 1$ da Lei n. ${ }^{\circ} 5 / 2002$, legitimam-se na presunção - estabelecida no artigo $7^{\circ},{ }^{\circ} .^{\circ} 1$ - de que "constitui vantagem de atividade criminosa a diferença entre valor do património do arguido e aquele que seja congruente com o seu rendimento lícito".

Trata-se de presunção que gerou, como se poderia imaginar, controvérsia doutrinal e jurisprudencial quanto à sua conformidade com princípios constitucionais e internacionais respeitantes, no essencial, à presunção de inocência e ao direito ao silêncio do arguido.

44 Para uma resenha de medidas tendentes a perda de vantagens (para além da "clássica") por determinados crimes em cumprimento de deveres internacionais ou europeus em alguns países europeus, veja-se CAEIRO, P.: "Sentido e função do instituto de perda de vantagens relacionadas com o crime no confronto com outros meios de prevenção da criminalidade reditícia (em especial, os procedimentos de confisco in rem e a criminalização do enriquecimento ilícito). RPCC, 21 (2011), pp. 278-289. 
No que se refere aos diplomas internacionais, o Tribunal Europeu dos Direitos Humanos (TEDH) foi chamado a pronunciar-se acerca da compatibilidade do confisco ampliado, previsto no Drug Trafficking Act de 1994, com o princípio da presunção da inocência sufragado pelo artigo $6 .^{\circ}, \S 2$ da Convenção Europeia dos Direitos Humanos (CEDH), a propósito do caso Philips vs. Reino Unido, em Acórdão de 5 de julho de 2001. Conforme dá nota Silva Dias, o TEDH centrou a sua argumentação em dois pontos essenciais: primeiro, «[...] ] confisco não implica uma nova acusação, nem uma nova condenação [...], antes [...] consiste numa operação análoga à determinação pelo Tribunal do montante da multa ou da medida da prisão a serem impostos a um sujeito já condenado»; segundo, «[...] pese embora a presunção de inocência» iluminar «o processo penal na sua totalidade e não somente os méritos da acusação, o princípio surge apenas em conexão com o crime que é objeto da acusação (e do processo) e, por isso, não é aplicável ao confisco» ${ }^{45}$. Acompanhamos as reservas de Silva Dias quanto a este segundo argumento ${ }^{46}$, dando, aliás, relevo à opinião contrária (a este segundo argumento) de dois juízes do $\mathrm{TEDH}^{47}$; melhor será perspetivar o confisco ampliado - na linha de pensamento de Silva Dias -

45 DIAS, S.: "Criminalidade organizada e combate ao lucro ilícito", em Maria Fernanda Palma e outros, $2 .^{\circ}$ Congresso de Investigação Criminal, Coimbra, 2010, pp. 42-43.

46 «Se não é aceitável circunscrever a presunção de inocência à questão da culpabilidade, colocando fora da sua alçada a questão da sanção, nem tão pouco fazer depender a força normativa do princípio da fase em que o processo se encontra, não é defensável também considerar a presunção de inocência um princípio absoluto, subtraído ao conflito e à ponderação prática» (DIAS, S.: "Criminalidade organizada e combate ao lucro ilícito", em Maria Fernanda Palma e outros, $2{ }^{\circ}$ Congresso de Investigação Criminal, Coimbra, 2010, p. 43).

47 Trata-se da «opinião divergente dos juízes Bratza e Vajic anexa ao Acórdão, contestando a posição maioritária dos juízes segundo a qual o art. $6 .^{\circ} \S 2$ da Convenção não é aplicável ao procedimento de confisco» (DIAS, S.: "Criminalidade organizada e combate ao lucro ilícito", em Maria Fernanda Palma e outros, $2 .^{\circ}$ Congresso de Investigação Criminal, Coimbra, 2010, p. 43 , nota 42 ). 
como consequência acessória da pena, constituindo um seu efeito (não automático) patrimonial, fundamentada (já o referimos) no horizonte político-criminal da clássica perda de vantagens relacionadas com o crime ${ }^{48}$.

Quanto à conformidade à nossa Lei Fundamental, também o Tribunal Constitucional se pronunciou sobre esta matéria nos Acórdãos n. ${ }^{\circ}$ s 101/2015, 392/2015 e 476/2015, dando relevo Euclides Simões e José Trindade, à conclusão do último Acórdão citado que "a presunção legal estabelecida nos artigos $7 .^{\circ}$ e $9 .^{\circ}$, n..$^{\circ}$ s 1,2 e 3 , da Lei n. ${ }^{\circ} 5 / 2002$, de 11 de janeiro, não viola o princípio da presunção de inocência ${ }^{49}$, nem

48 Qual seja (nas palavras de Silva Dias): «reforçar na consciência coletiva o lema de que o crime não compensa e evitar que o património obtido de forma criminosa organizada seja utilizado para cometer novos crimes ou para ser "investido" na economia legal». Concluímos, assim, com o A. que a sua natureza é «eminentemente penal, constituindo [...] um efeito da pena» (DIAS, S.: "Criminalidade organizada e combate ao lucro ilícito", em Maria Fernanda Palma e outros, 2. ${ }^{\circ}$ Congresso de Investigação Criminal, Coimbra, 2010, p. 39). Já natureza diferente assume a chamada actio in rem. Trata-se de procedimento de natureza administrativa, «dirigido contra coisas de origem suspeita (a civil forfeiture do direito estadunidense ou a civil recovery do direito britânico), impondo aos pretensos titulares que provem a legitimidade da sua pretensão ou a titularidade dos bens, sob pena de os perderem para o Estado» (CAEIRO, P.: "Sentido e função do instituto de perda de vantagens relacionadas com o crime no confronto com outros meios de prevenção da criminalidade reditícia (em especial, os procedimentos de confisco in rem e a criminalização do enriquecimento ilícito). RPCC, 21 (2011), p. 278). O TEDH, no caso Gogitidze and Others vs. Georgia, em Acórdão tirado por unanimidade em 12 de maio de 2015, pronunciouse pela congruência da actio in rem com o artigo $1 .^{\circ}$ do Protocolo n..$^{\circ} 1$ à $\mathrm{CEDH}$, ainda que a enquadre como procedimento cível, legitimando a inversão do ónus de provar que os rendimentos são lícitos (sobre este Acórdão e implicações envolventes, veja-se SIMÕES, E. D. e TRINDADE, J. L.: "Recuperação de Activos - Confisco sem acção penal - A "actio in rem" na jurisprudência do Tribunal Europeu dos Direitos Humanos". Julgar on-line, março de 2016, pp. 1-8).

49 No que se refere especificamente à presunção de inocência, pode ler-se na fundamentação do Acórdão n. ${ }^{\circ}$ 101/2015: «Na verdade [...], a "presunção" contida no n. ${ }^{\circ} 1$ do artigo $7 .^{\circ}$ da Lei ${ }^{\circ}{ }^{\circ} 5 / 2002$ apenas opera após a condenação, em nada contrariando, pois, a presunção de inocência, consagrada no n. ${ }^{\circ} 2$ do artigo $32 .^{\circ}$ da CRP. Além do mais, trata-se de uma presunção 
o direito do arguido ao silêncio, nem a estrutura acusatória do processo penal" ${ }^{50}$.

Recentemente, transpondo a Diretiva 2014/42/EU, do Parlamento Europeu e do Conselho, de 3 de abril, sobre o congelamento e a perda dos instrumentos e produtos do crime na União Europeia $^{51}$, veio a já mencionada Lei n. ${ }^{0}$ 30/2017, de 30 de maio, atualizar a Lei . $^{\circ}$ 5/2002, de 11 de janeiro. A Diretiva, sublinhando alguma ineficácia dos regimes de confisco ampliado dos Estados-Membros no combate ao lucro ilícito ${ }^{52}$, impõe a necessidade de confiscar bens que não provenham diretamente do crime pelo que o arguido foi condenado, mas que sejam produto de outros crimes ${ }^{53}$, de evitar que esses bens sejam transferidos para terceiros - o que implica «uma atuação urgente quando necessário para preservar os bens» ${ }^{54}-\mathrm{e}$, bem assim, de confiscar bens que se encontrem já na posse de terceiros (desde que se não prejudique direitos de terceiros de boa-fé) ${ }^{55}$.

ilidível, como são todas as presunções legais exceto quando o legislador disponha em contrário (artigo $350 .^{\circ}$, n. $^{\circ} 2$, do Código Civil). O princípio de que parte o legislador ao estabelecê-la - princípio cuja não verificação o recorrente sempre poderia ter demonstrado - é o de que ocorreu no caso um ganho ilegítimo, proveniente da atividade criminosa, compreensivelmente reportada ao rendimento do condenado que exceda o montante do seu rendimento lícito» (disponível na Internet em http://www.tribunalconstitucional. pt/tc/acordaos/20150101.html, acedido em 1 de novembro de 2017).

50 SIMÕES, E. D. e TRINDADE, J. L.: "Recuperação de Activos - Confisco sem acção penal - A “actio in rem" na jurisprudência do Tribunal Europeu dos Direitos Humanos". Julgar on-line, março de 2016, p. 6.

51 Diretiva 2014/42/UE 2005, de 3 de abril, em Jornal Oficial da União Europeia, de 29.4.2014.

52 Veja-se, v.g., Consideração (4), em Jornal Oficial da União Europeia, L 127/39, de 29.4.2014.

53 Veja-se, por exemplo, Considerações (11) e (19), em Jornal Oficial da União Europeia, L 127/40 e L 127/41, de 29.4.2014.

54 Artigo 7. ${ }^{\circ}$, em Jornal Oficial da União Europeia, L 127/47 de 29.4.2014. Trata-se do que a Diretiva designa - pode ler-se no mesmo artigo $7 .^{\circ}$ - como «congelamento de bens, tendo em vista uma eventual decisão de perda subsequente».

55 Cf. Consideração (24) e artigo 6. ${ }^{\circ}$, em Jornal Oficial da União Europeia, L $127 / 43$ e L $127 / 47$ de 29.4.2014. 
Em transposição da Diretiva, a Lei n. ${ }^{\circ} 30 / 2017$, alterou a Lei n. ${ }^{\circ} 5 / 2002$, antecipando, ainda mais, o arresto preventivo ao estabelecer, no artigo $10 .^{\circ}$, n. $^{\circ} 2$, que, a «todo o tempo, logo que apurado o montante da incongruência, se necessário ainda antes da própria liquidação, quando se verifique cumulativamente a existência de fundado receio de diminuição das garantias patrimoniais e fortes indícios da prática do crime, o Ministério Público pode requerer o arresto de bens do arguido no valor correspondente ao apurado como constituindo vantagem de atividade criminosa». Torna-se mais preventivo o arresto, ao poder ser decretado pelo Ministério Público antes mesmo da liquidação - vale por dizer, durante a fase do inquérito - desde que se apure existência de incongruência patrimonial e fortes indícios da prática do crime $^{56}$.

\section{Deteção, recuperação e gestão do lucro injustificado}

Partindo o instituto do confisco ampliado da incongruência entre real património do arguido e respetivos rendimentos lícitos, toma especial relevância, antes de mais, nesta matéria, a capacidade de deteção e avaliação do real património do arguido.

Dada a consabida propensão para a circulação de rendimentos ilícitos no plano internacional, a União Europeia, através da Decisão-Quadro 2007/845/JAI do Conselho, promoveu a cooperação relativa à deteção e identificação das vantagens do crime. Para o efeito, é determinada a obrigação de criação, nos Estados-Membros, de gabinetes nacionais de recuperação de bens com o objetivo de «facilitar a deteção e identificação de produtos e outros bens relacionados com o crime suscetíveis de serem objeto de uma ordem de congelamento, apreensão ou perda emi-

56 Para uma análise aprofundada das garantias processuais do confisco (apreensão, caução económica, arresto, arresto para perda alargada), que naturalmente variam «conforme os interesses penais que a norma visa tutelar e a gravidade da restrição em causa» (p. 506), veja-se CORREIA, J. C.: "Apreensão ou arresto preventivo dos proventos do crime?". RPCC, 25 (2015), pp. 505-543. 
tida por uma autoridade judiciária competente no decurso de um processo penal» $»^{57}$, devendo, esses Estados-Membros, «garantir que os seus gabinetes de recuperação de bens cooperem entre si [...], procedendo a intercâmbios de informações e boas práticas, quer a pedido, quer espontaneamente» ${ }^{58}$, de modo a que se possa garantir essa troca de informações com celeridade ${ }^{59}$.

Neste quadro, a Lei n. ${ }^{\circ}$ 45/2011, de 24 de junho, criou em Portugal, na dependência da Polícia Judiciária (PJ), o Gabinete de Recuperação de Ativos (GRA) ${ }^{60}$, conformando a determinação da mencionada Decisão-Quadro do Conselho da União Europeia.

Considerando a versão atualizada (por último, pela Lei n. ${ }^{\circ}$ 30/2017, de 30 de maio), da Lei n. ${ }^{\circ} 45 / 2011$, tendo como missão (artigo $4^{\circ}{ }^{\circ}$ ) proceder à identificação, localização e apreensão de bens ou produtos relacionados com crimes, o GRA, com atribuições de investigação análogas às dos órgãos de polícia criminal (OPC) (artigo 2..$^{\circ}$ ), constitui-se, nas palavras de Conde Correia, em «pedra angular do sistema português do confisco ${ }^{61}$. Por determinação do Ministério Público, compete-lhe a investigação da situação patrimonial e financeira do arguido, paralela (acessória) à investigação criminal. Para o efeito, a sua «principal ferramenta é [...] o acesso privilegiado a uma série de bases de dados fundamentais para traçar o perfil económico do visado ${ }^{62}$, nomeadamente do Instituto dos Registos e Nota-

57 Artigo $1 .^{\circ}$, n. $^{\circ} 1$ da Decisão-quadro 2007/845/JAI do Conselho, de 6 de dezembro (Jornal Oficial da União Europeia de 18.12.2007, L 332/104).

58 Artigo 2. ${ }^{\circ}$, n. $^{\circ} 1$ da Decisão-quadro (L 332/104).

59 Conforme se prescreve na Consideração (4), ainda do mesmo diploma (L 332/103).

60 A efetiva criação ocorreu em finais de 2012, após publicação da Portaria dos Ministérios das Finanças e da Justiça n. ${ }^{\circ}$ 269/2012, de 3 de setembro.

61 CORREIA, J. C.: "Gabinete de recuperação de ativos: pedra angular do sistema português de confisco". Revista de Investigação Criminal, Ciências Criminais e Forenses, $2 .^{\circ}$ semestre (2017), pp. 46-65.

62 CORREIA, J. C.: "Gabinete de recuperação de ativos: pedra angular do sistema português de confisco". Revista de Investigação Criminal, Ciências Criminais e Forenses, $2 .^{\circ}$ semestre (2017), p. 57. 
riado (IP); da Autoridade Tributária e Aduaneira; da Segurança Social; da Autoridade de Supervisão de Seguros e Fundos de Pensões; da Comissão de Mercado de Valores Mobiliários; do Banco de Portugal; da Autoridade Nacional de Aviação Civil; e da Direção-Geral da Autoridade Marítima (artigo 8. ${ }^{\circ}$, n. $^{\circ} 2$ ). «Desta forma, através da consulta e do estudo de documentos aí existentes, o GRA procura começar a reconstruir a verdade patrimonial e financeira do visado ${ }^{63}$. Ao Ministério Público, no contexto da investigação de incongruência de património de arguido, é, assim, atribuído o poder de solicitar, às Instituições referidas, as informações necessárias para deteção do património incongruente, isto é, do património a confiscar.

Uma vez decretado o confisco (consequência acessória) na sentença condenatória de arguido por crime de catálogo (onde se incluem os crimes de corrupção), a administração dos respetivos bens é assegurada pelo Gabinete de Administração de Bens (GAB), integrado no Instituto de Gestão Financeira e Equipamentos da Justiça (IGFEJ/IP) (artigo 10. ${ }^{\circ}$, n. $^{\circ} 1$ ). Ao GAB são-lhe conferidas, entre outras, competências para proteger, conservar e gerir os bens confiscados, determinar a sua venda ou afetação ao serviço público (v.g., atribuir equipamentos aos OPC) ou, quando se justifique, a própria destruição de bens ${ }^{64}$.

63 CORREIA, J. C.: "Gabinete de recuperação de ativos: pedra angular do sistema português de confisco". Revista de Investigação Criminal, Ciências Criminais e Forenses, $2 .^{\circ}$ semestre (2017), p. 57. Destacamos, neste âmbito, a versão atualizada do Regime Geral das Instituições de Crédito e Sociedades Financeiras (RGICSF) - desde alteração introduzida pelo Decreto-Lei 31-A/2012, de 10 de fevereiro (última atualização: Lei n. ${ }^{\circ}$ 30/2017) - que determina, no quadro das exceções ao dever de sigilo bancário, a obrigação de revelar factos e elementos (cobertos pelo segredo) "às Autoridades Judiciárias, no âmbito de um processo penal” (artigo 79. ${ }^{\circ}, \mathrm{n} .^{\circ} 2, d$ ) do RGICSF).

64 Quanto ao regime jurídico completo da administração dos bens apreendidos, recuperados ou confiscados, veja-se o Capítulo III ( $\operatorname{artigos~} 10 .^{\circ}$ a $18 .^{\circ}$ ) da versão atualizada da Lei n. ${ }^{\circ}$ 45/2011, de 24 de junho. 


\section{Considerações finais}

Com o presente trabalho procurou-se sublinhar o essencial das alterações legislativas implementadas nos últimos anos (conformando obrigações internacionais) em Portugal, com vista a um mais eficaz combate à corrupção pública e ao confisco do lucro injustificado que dela possa provir.

Estas alterações não se anteveem, obviamente, como panaceia milagrosa desejada por quem advoga maior eficácia no combate à corrupção e aos respetivos lucros ilícitos. Longe disso. Dificilmente as alterações legislativas o serão, de resto, em qualquer matéria criminal - e não só. Tanto mais quando se trata de criminalidade tendencialmente organizada e transfronteiriça.

Espera-se, contudo, que possam contribuir, em conjunto com outras medidas no plano operativo e com organismos que atuem pedagogicamente no plano social ( $v . g$, o Conselho de Prevenção para a Corrupção), para aumentarem tal eficácia, dissuadindo a prática corruptiva, mantendo-a, ao menos, em níveis comunitariamente suportáveis. Dentro - nisso não se concede da equilibrada concordância prática entre a realização da justiça e a tutela dos direitos fundamentais, própria das democracias liberais, caracterizadas, na sua essência, por não absolutizarem (nem "fundamentalizarem") valores ou direitos. Tal como desentranha do artigo $18 .^{\circ}$, n. $^{\circ} 2$ da nossa Lei Constitucional.

\section{Bibliografia}

AlBuQuerQue, P.: Comentário do Código Penal à luz da Constituição da República e da Convenção Europeia do Direito do Homem, 3. a ed., Lisboa, 2015.

ALMEIDA, C. R.: "Criminalidade organizada e corrupção", em Maria Fernanda Palma e outros, $2{ }^{\circ}$ Congresso de Investigação Criminal, Coimbra, 2010, pp. 49-56.

BELEZA, T.: ““"Tão amigos que nós erámos”: o valor probatório do depoimento do co-arguido no processo penal português". RMP, 19, n. ${ }^{\circ} 74,1998$, pp. 39-60. 
CAEIRO, P.: "Sentido e função do instituto de perda de vantagens relacionadas com o crime no confronto com outros meios de prevenção da criminalidade reditícia (em especial, os procedimentos de confisco in rem e a criminalização do enriquecimento ilícito). RPCC, 21 (2011), pp. 267-321.

CAMPOS, L.: "A corrupção e a sua dificuldade probatória - o crime de recebimento indevido de vantagem". $R M P$, ano 35 (2014), 137, pp. 117-146.

CORREIA, J. C.: "Apreensão ou arresto preventivo dos proventos do crime?". RPCC, 25 (2015), pp. 505-543.

CORREIA, J. C.: "Gabinete de recuperação de ativos: pedra angular do sistema português de confisco". Revista de Investigação Criminal, Ciências Criminais e Forenses, $2{ }^{\circ}$ semestre (2017), pp. 46-65.

CUNHA, D.: "Da corrupção (Do seu enquadramento jurídico no âmbito da tutela penal dos interesses do Estado. Erros legislativos e lacunas de punibilidade), em Manuel da Costa Andrade e outros, Direito Penal - Fundamentos Dogmáticos e Político-Criminais. Homenagem ao Prof. Peter Hünerfeld; Coimbra, 2013, pp. 849-918.

CUNHA, D.: "As alterações legislativas em matéria de corrupção (a Lei 30/2015, de 22 de abril, e suas consequências)". Julgar Online, 2016, pp. 4-30.

DIAS, S.: "Criminalidade organizada e combate ao lucro ilícito", em Maria Fernanda Palma e outros, $2{ }^{\circ}$ Congresso de Investigação Criminal, Coimbra, 2010, pp. 23-47.

FERNANDES, L. C.: Teoria Geral do Direito Civil, II, 5. ed., Lisboa, 2010.

LEITE, I.F.: ““"Arrependido”: a colaboração processual do coarguido na investigação criminal", em Maria Fernanda Palma e outros, $2{ }^{\circ}$ Congresso de Investigação Criminal, Coimbra, 2010, pp. 381-410.

MENDES, P. S.: "Os novos crimes de recebimento e de oferta indevida de vantagem", em Rui Carmo e Helena Leitão (coord.), As Alterações de 2010 ao Código Penal e ao Código de Processo Penal, Coimbra, 2011, pp. 29-41. 
TORRÃO, F.: "Princípio da oportunidade no quadro da criminalidade organizada e económico-financeira. Em especial a figura do "arrependido-colaborador"”, em Manuel Guedes Valente (coord.), IV Congresso de processo Penal -I Congresso Luso-Brasileiro de criminalidade económicofinanceira, Coimbra, 2016, pp. 157-174.

SANTIAGO R., "Reflexões sobre as declarações do arguido como meio de prova no Código de Processo Penal de 1987'. RPCC, 4, n. ${ }^{\circ} 1,1994$, pp. 27-62.

SANTOS, C.: "A corrupção [Da luta contra o crime na intersecção de alguns (distintos) entendimentos da doutrina, da jurisprudência e do legislador", em Manuel da Costa Andrade e outros, Liber Discipulorum para Jorge de Figueiredo Dias, Coimbra, 2003, pp. 963-991.

SANTOS, C.: "Notas breves sobre os crimes de corrupção de agentes públicos". Julgar, n. ${ }^{\circ} 11,2010$, p. 51-58.

SANTOS, C.: "Os crimes de corrupção de funcionários e a Lei n. ${ }^{\circ} 32 / 2010$, de 2 de setembro", em Rui Carmo e Helena Leitão (coord.), As Alterações de 2010 ao Código Penal e ao Código de Processo Penal, Coimbra, 2011, pp. 9-28.

SEIÇA, M.: O conhecimento probatório do co-arguido, Coimbra, 1999.

SILVA, G. M.: "Bufos, infiltrados, provocadores e arrependidos: os princípios democráticos e da lealdade em processo penal”. Direito e Justiça, Lisboa, ano VIII (1998), Tomo 2, Lisboa, pp. 27-34.

SIMÕES, E.: "Contra a Corrupção (Propostas terapêuticas para uma endemia antiga. Julgar Online, 2014, pp. 1-14.

SIMÕES, E. D. e TRINDADE, J. L.: "Recuperação de Activos - Confisco sem acção penal - A "actio in rem" na jurisprudência do Tribunal Europeu dos Direitos Humanos". Julgar on-line, março de 2016, pp. 1-8.

VASCONCELOS, P. P.: Teoria Geral do Direito Civil, 8. ${ }^{\mathrm{a}}$ ed., Coimbra, 2015. 